\title{
Effects of Electronic Banking on Agricultural Entrepreneurs
}

\section{Bilal Ahmad Sheikh ${ }^{1 *}$, Sudhakar Dwivedi ${ }^{2}$ and Omar Fayaz Khan ${ }^{1}$}

${ }^{1}$ Sher-e-Kashmir University of Agricultural Sciences and Technology of Kashmir, Kashmir, JEK, India

${ }^{2}$ Sher-e-Kashmir University of Agricultural Sciences and Technology of Kashmir, Jammu, JEK, India

*Corresponding author: bhat_bilal@rediffmail.com

Received: $19-08-2020$

Revised: $22-10-2020$

Accepted: 30-11-2020

\section{ABSTRACT}

E-banking services are an innovative financial transaction channel that has assumed a new urgency and relevance in today's world of business, demand for financial products is changing rapidly and agricultural entrepreneurs behavior regarding these products is also changing, with the passing of the traditional banking sector to e-banking, new strategies have become necessary in order to attract new customers and retain existing customers, the present study attempts to provide a snapshot of e-Banking usage by agricultural entrepreneurs with empirical details supporting the findings. Based on the survey data generated through 83 agricultural entrepreneurs where analyzed and the corresponding findings are discussed in the work

Keywords: e-Banking, Adoption of e-Banking, Financial products via e-Banking

\section{Electronic Banking}

The expression "e-banking" has been utilized in writing from various perspectives, incompletely in light of the fact that electronic financial alludes to a few kinds of administrations through which banks and clients can demand data and do most retail banking administrations by means of the web, or cell phones (Roshan et al. 2012). As a rule, E-banking implies giving financial items and administrations straightforwardly to clients through electronic, intuitive correspondence channels (Karjaluoto, 2009). However, a more exhaustive and basic definition for e-banking comes from the Basel Committee Report on financial management. The Basel Committee characterizes e-banking as. The arrangement of retail and little worth financial items and administrations through electronic channels, such items and administrations can incorporate store taking, loaning, account the executives, the arrangement of monetary exhortation, electronic bill installment items and administrations, for example, electronic cash e-banking in India arose in mid nineties as recently presented private area banks thought of another plan of action rotating around a solid data innovation (IT) spine. Web bank in India was started by ICICI bank, a private bank, in 1998. Following this, countless government banks just as private banks picked offering web banking administration (Kesharwani et al. 2007). The number of bank clients who utilizes web banking as one of the medium to perform banking exercises has likewise been kept on developing (Malhotra and Singh, 2007). E-Banking including Viewing Transaction Details, Downloading of Transaction Details, Fund Transfer, Request for DD/Accounts' Statement/

How to cite this article: Sheikh, B.A., Dwivedi, S. and Khan, O.F. (2020) Effects of Electronic Banking on Agricultural Entrepreneurs. Agro Economist - An International Journal, 7(2): 153-158.

Source of Support: None; Conflict of Interest: None 
Check Book Issue/Stop-Payment of check/RevokeStop Payment/S.I. creation/S.I. Scratch-off/S.I. Correction, On-Line Bill Payments and On-Line installment of Direct/Indirect charges.

\section{Introduction to Agribusiness}

Agribusiness is an expansive idea used to portray corporate farming ventures separately and aggregately. Agribusinesses are organizations engaged with at least one phases of the creation of yields and domesticated animals. Instances of agribusiness exercises incorporate:

- Research and advancement of new farming assets and strategies.

- Ownership or the board of agrarian creation offices, for example, farmlands and domesticated animals offices.

- Manufacture or appropriation of farming supplies and gear, for example, apparatus, feed, and manures.

- Processing or appropriation of farming items.

The expression "agribusiness" was begat during the 1950s by John Herbert Davis and Ray A. Goldberg to mirror the two-path reliance among financial specialists and ranchers in the double functions of providers and buyers. Business firms that serve horticulture depend on ranchers for their business sectors and for a portion of their provisions. By a similar token, ranches couldn't work without organizations that assembling ranch supplies and those that store, cycle, and product ranch wares.

In the mid nineteenth century, farming was an independent industry. The average homestead family delivered its own food, fuel, cover, draft creatures, feed, apparatuses, executes, and in any event, attire. A couple of necessities must be bargained for or bought off the homestead. The homestead family performed practically all activities relating to the creation, preparing, stockpiling, and circulation of ranch wares. In the resulting years, notwithstanding, agribusiness advanced from independence to many-sided reliance with different sections of the economy, especially those identifying with the assembling of creation supplies and the preparing and appropriation of food and fiber items.
The present study is aimed at knowing the influence of e-Banking on Agricultural Entrepreneurs in Union Territory of Jammu and Kashmir.

\section{MATERIALS AND METHODS}

Bindiya et al. (2011) investigated that all the banks are utilizing data innovation as an essential vehicle to remain serious against different players. Banking innovation helps in expanding consumer loyalty, client reliability, ad libbed development, and execution of the banks. The impression of Indian clients towards the utilization of innovations concerning components, for example, accommodation, protection, security, convenience, constant availability, and exact record of shifted exchange that empower client's appropriation of Banking Technology. Different factors, for example, slow exchange speed, specialized disappointment, cheats and ignorance among clients that make obstruction in selection of web banking were likewise clarified, in this examination. Further, the aftereffects of this work show that segment factors, for example, sex, age, capability and pay assume a positive part in selection of banking innovation. While as Mohammad et al. (2012) have detailed that e-banking administrations are being utilized with expanding recurrence in many nations. Also Margaret et al. (2000) reports that goal to receive Internet banking administrations can be anticipated by attitudinal and saw conduct control factors, however not by emotional standards. Two extra impacting factors (emotional standards and saw conduct control) proposed by (Ajzen, 1985) in the hypothesis of arranged conduct, were remembered for this investigation. Specifically, self-productivity toward utilizing Internet banking administrations and the encouraging state of apparent government uphold for Internet trade, were both found to essentially influence expectations to receive Internet banking administrations, however Lichtenstein et al. (2006) reports key discoveries from an interpretive investigation of Australian banking, that a comprehension of how and why explicit elements influence the buyer choice whether to rely upon the Internet, in the Australian setting. Meanwhile Ming et al. (2008) considered that web based banking (Internet banking) has arisen as one of the most productive online business applications throughout the most recent decade. 
Similarly Thompson et al. (2011) investigated an examination system dependent on the hypothesis of arranged conduct (Ajzen, 1985), and the dispersion of developments hypothesis (Rogers, 1983), was utilized to distinguish the attitudinal, social and saw social control factors that would impact the appropriation of Internet banking. However Kaleem and Ahmad (2007) see danger with regards to security concerns, and trust in one's bank, which demonstrates that apparent danger is identified with dependability and framework disappointment. Lichtenstein and Williamson (2006) demonstrate that security, protection, trust and danger concerns may affect purchaser web banking appropriation. They further demonstrate that $80 \%$ of worldwide phishing assaults in the main quarter of 2005 focused on the monetary administrations area Daniel (1999) characterized Internet banking administrations as significant data administrations of a bank to serve its clients by means of the Internet. Mukherjee and Nath (2003) characterized Internet banking as a kind of banking movement through which customers can perform banking exchanges, for example, financial records adjusts and making installments by means of media transmission organization. Encarta MSN (2007) characterized Internet banking as administrations of banks in which the clients can take care of tabs and check account data by the utilization of the Internet. Regarding Internet banking, a typical disarray exists between the expressions "Web banking" and "PC banking". "Web banking" includes the utilization of banking administrations through the World Wide Web.

\section{Sampling Details}

The primary data for the present Study was collected from the Banking Customers who are agricultural entrepreneurs and these customers were identified on random basis from the Union Territory of Jammu and Kashmir, the filled up response was collected successfully from 100 respondents, however from collected 100 responses 83 responses were valid and 17 responses was incomplete and hence eliminated from the current study. Hence the sample size for the present work is treated as 83 comprising the Agricultural Entrepreneurs who were banking customers of different Banks. Thus, the sampling procedure adopted for the present study is treated as stratified random sampling method. The primary data for the present study is collected between the periods June 2020 to August 2020. The data collected were coded and transferred in to Statistical package for Social Science (SPSS) for the purpose of analysis.

\section{RESULTS AND DISCUSSION}

\section{Banking requirement fulfillment}

Based on customers' survey, $43 \%$ of Banking requirements are being fulfilled by Jammu and Kashmir Bank and rest $57 \%$ of banking requirements are being fulfilled by other different banks as shown in Table 1, so Jammu and Kashmir stands $1^{\text {st }}$ while fulfilling Banking requirements of agricultural entrepreneurs. $32 \%$ of banking requirements are being fulfilled by State bank of India and hence State Bank of India Stands $2^{\text {nd }}$ while fulfilling Banking requirements of agricultural entrepreneurs. $11 \%$ of Banking requirements are being fulfilled by Punjab national bank, $7 \%$ by HDFC bank, $5 \%$ by cooperative Bank similarly Punjab national bank stands $3^{\text {rd }}$, HDFC bank $4^{\text {th }}$, Co-operative bank $5^{\text {th }}$ while fulfilling the banking requirements of agricultural entrepreneurs. Axis Bank fulfills 4\%, Elaqahi Dehati Bank 4\%, Jk Grameen Bank 4\%, Central Bank of India $4 \%$, Indian bank $4 \%$ and hence stands in $6^{\text {th }}$ position while fulfilling the Banking Requirements of agricultural entrepreneurs.

Table 1: Banks cited by customers

\begin{tabular}{llll}
\hline Banks cited by customers & $\begin{array}{l}\text { Banking requirement } \\
\text { fulfillment }\end{array}$ & $\begin{array}{l}\text { Banks cited by } \\
\text { customers }\end{array}$ & $\begin{array}{l}\text { Banking requirement } \\
\text { fulfillment }\end{array}$ \\
\hline Jammu and Kashmir Bank & $43 \%$ & Axis Bank & $4 \%$ \\
State Bank of India & $32 \%$ & Ellaqahi Dehati Bank & $4 \%$ \\
Punjab National Bank & $11 \%$ & JK Grameen Bank & $4 \%$ \\
HDFC Bank & $7 \%$ & Central Bank of India & $4 \%$ \\
Co-operative Bank & $5 \%$ & Indian Bank & $4 \%$ \\
\hline
\end{tabular}




\section{Fulfillment of banking requirement}

$96 \%$ of banking requirements are being fulfilled through the usage of Automated Teller Machines (ATM), 4\% of agricultural entrepreneurs are non users of ATM services, $30 \%$ of agricultural entrepreneurs use ATM services on low levels, 25\% on medium levels and $41 \%$ on high levels. Hence, Automated Teller Machine Stands $1^{\text {st }}$ while fulfilling the Banking requirements of Customers.76\% of Banking requirements are being Fulfilled by Visiting Bank Branch, 24\% of agricultural entrepreneurs are not visiting Bank branch, $20 \%$ of agricultural entrepreneurs are visiting Bank branch on low levels, $26 \%$ agricultural entrepreneurs are visiting Bank branch on medium levels and 30\% of agricultural entrepreneurs are visiting bank branch on high levels. Therefore visiting Bank branch stands $2^{\text {nd }}$ while Fulfilling Banking requirements of agricultural entrepreneurs. $60 \%$ of Banking requirements of agricultural entrepreneurs are being fulfilled by the use of e banking, $40 \%$ of agricultural entrepreneurs are Non users of e Banking Services, 25\% are using internet Banking on low levels, $15 \%$ of agricultural entrepreneurs are medium users of Internet banking, $20 \%$ of agricultural entrepreneurs are high users of internet banking and hence Internet Banking Stands $3^{\text {rd }}$ while fulfilling the requirements of Banking, as shown in Table 2.

\section{Linear Regression between Internet Banking and} Financial products

The Intensity of Internet Banking Usage among agricultural entrepreneurs has been conceptualized as the function of utilization of online financial. The details of online financial services considered in the present work include Investments on Derivatives through Internet Banking, Paying Insurance Premium through Internet Banking, Mutual Funds Investments through Internet Banking, Investments on Futures and Options through Internet Banking, Online share trading, Exploiting the potentials of

Table 2: Banking Requirement Fulfillment.

\begin{tabular}{llllll}
\hline Types of Banking Method & $\begin{array}{l}\text { Banking requirement } \\
\text { fulfillment }\end{array}$ & $\begin{array}{l}\text { Non } \\
\text { users }\end{array}$ & Low usage & $\begin{array}{l}\text { Medium } \\
\text { usage }\end{array}$ & $\begin{array}{l}\text { High } \\
\text { usage }\end{array}$ \\
\hline Automated Teller Machine (ATM) & $96 \%$ & $4 \%$ & $30 \%$ & $25 \%$ & $41 \%$ \\
Visiting Bank Branch & $76 \%$ & $24 \%$ & $20 \%$ & $26 \%$ & $30 \%$ \\
Internet Banking & $60 \%$ & $40 \%$ & $25 \%$ & $15 \%$ & $20 \%$ \\
\hline
\end{tabular}

Table 3: Linear Regression between Internet Banking and Financial products

\begin{tabular}{|c|c|c|c|c|c|c|}
\hline \multirow[t]{2}{*}{ Model } & \multicolumn{2}{|c|}{$\begin{array}{l}\text { Unstandardized } \\
\text { Coefficients }\end{array}$} & \multirow{2}{*}{$\begin{array}{l}\text { Standardized } \\
\text { Coefficients } \\
\text { Beta } \\
\end{array}$} & \multirow[b]{2}{*}{$t$} & \multirow{2}{*}{$\mathbf{F}$} & \multirow{2}{*}{$\begin{array}{l}\text { Adjusted R } \\
\text { Square }\end{array}$} \\
\hline & B & Std. Error & & & & \\
\hline (Constant) & 0.201 & 0.106 & & 1.893 & & \\
\hline $\begin{array}{l}\text { Investments on Derivatives through Internet } \\
\text { Banking }\end{array}$ & 0.391 & 0.214 & 0.270 & 1.832 & & \\
\hline Mutual funds Investments & -0.386 & 0.194 & -0.260 & $-1.995^{*}$ & & \\
\hline $\begin{array}{l}\text { Investments on Futures and Options through } \\
\text { Internet Banking }\end{array}$ & -0.190 & 0.135 & -0.148 & -1.403 & & \\
\hline Online share trading & -0.445 & 0.121 & -0.364 & $-3.671^{*}$ & 28.847 & 0.758 \\
\hline $\begin{array}{l}\text { Having opened Saving Bank Account Online } \\
\text { for you and also for others }\end{array}$ & 0.410 & 0.113 & 0.369 & $3.616^{*}$ & & \\
\hline $\begin{array}{l}\text { Electronic Fund Transfer (NEFT RTGS IMPS) } \\
\text { through Internet Banking }\end{array}$ & 0.297 & 0.082 & 0.267 & $3.617^{*}$ & & \\
\hline Loan EMI Payments through internet & 0.331 & 0.155 & 0.149 & $2.133^{*}$ & & \\
\hline Income tax and other Taxes & -0.575 & 0.161 & -0.448 & $-3.572^{*}$ & & \\
\hline
\end{tabular}


Savings Bank account through Internet Banking, Electronic Fund Transfer like NEFT, RTGS and IMPS through Internet Banking and Loan EMI Payments through Internet Banking. Thus, the Intensity of Internet Banking Usage as a function of the above listed online financial services has been conceptualized as a regression model and its results are shown in table $3^{\text {rd }}$. From the results, it can be inferred that the $\mathrm{F}$ value of 28.847 is found to be significant at 5 percent level these results suggest that Intensity of Internet Banking usage among the agricultural entrepreneurs depends on their utilization of online financial products. Further the adjusted R Square value of 0.758 from the table $3^{\text {rd }}$ indicate that 75.8 percent Internet banking usage among the agricultural entrepreneurs depends on the considered group of online financial products. Also, the $t$ values of 1.995, 1.403, 3.671, $-3.616,3.617,2.133,4.028,5.222,-03.216,-05.864$, $2.134,5.766,-03.572,2.307$ Corresponding to all online Financial products Usage such as Investments on Derivatives through Internet Banking, Paying Insurance Premium through Internet Banking, Mutual funds Investments, Investments on Futures and Options through Internet Banking, Online share trading, Exploiting the potentials of Savings Bank account through Internet Banking, Electronic Fund Transfer (NEFT RTGS IMPS) through Internet Banking, Loan EMI Payments through internet, Electricity Bill, Income tax and other Taxes are found to be having Significant effect on Internet Banking usage among agricultural entrepreneurs.

\section{CONCLUSION}

Electronic banking is safe and secure banking in Indian banking system but still the usage rates of electronic banking by agricultural entrepreneurs in India market are very low. The reasons for low adoption of e banking services in India by agricultural entrepreneurs is lack of knowledge regarding e banking services, fear of loss of money due to hackers and uneducated agricultural entrepreneurs. E-banking services are an innovative financial transaction channel that has assumed a new urgency and relevance in today's world of business, demand for financial products is changing rapidly and customer behavior regarding these products is also changing, with the passing of the traditional banking sector to e-banking. Hence, the Indian banking industry should organize demos and events and motivate agricultural entrepreneurs for usage of electronic banking in rural and sub urban areas to promote digital banking objective of Government of India.

\section{REFERENCES}

Ajzen, I. 2002. Perceived behavioral control, self-efficacy, locus of control, and the theory of planned behavior. Journal of Applied Social Psychology, 3(2): 665-683.

Ankit, Kesharwani. 2007. Drivers and Inhibitors of Internet Banking Adoption in India. Journal of Internet Banking and Commerce, 18(3): 01-18.

Aladwani, M. 2001. Online banking, A field study of drivers, development challenges, and expectations. International Journal of Information Management, 21: 213-225.

Bindiya, T., Tanwar, M. and Murari, K. 2011. Customer Adoption of Banking Technology in Private Banks of India. International Journal of Banking and Finance, 8(3): 73-88.

Basel Committee Report on Banking Supervision. 1998. Risk management for electronic banking and electronic money activities. Switzerland: bank of International settlements.

Alam, D. 2012. Electronic banking challenges in India. Interdisciplinary Journal of Contemporary Research in Business, 2(4): 31-45.

Gupta, P.K. 2008. Internet banking in India: consumer concerns and bank strategies. Global Journal of Business Research, 2(1): 43-51.

Hawkins, J.D. 2004. Internet Banking - Challenges for banks and regulators. Journal of Banking in the New Millennium, 16(3): 25-32.

Hofstede, G. 2007. A European in Asia. Asian Journal of Social Psychology, 10(3): 16-25.

Chavan, J. 2013. Internet banking- benefits and challenges in an emerging economy. International Journal of Research in Business Management, 1(1): 19-26.

Kannabiran, G. and Narayan, P.C. 2009. Deploying internet banking and e-commerce - case study of private sector banks in India. Information Technology for Development, 11(4): 363-379.

Kurnia, S. 2008. Exploring E-Commerce Readiness in China: The Case of the Grocery Industry. In Proceedings of the $41^{\text {st }}$ Annual Hawaii. International Conference. International Journal of Electronic Commerce, 10(4): 9-45.

Lichtenstein, S. and Williamson. 2006. Understanding consumer adoption of internet banking: an interpretive study in the Australian banking context. Journal of Electronic Commerce Research, 7(2): 50-66.

Mohamed, I. 2012. Factors Influencing the Adoption of E-banking in Sudan: Perceptions of Retail Banking 
Clients. Journal of Internet Banking and Commerce, 17(3): 01-17.

Margaret and Thompson. 2000. Factors Influencing the Adoption of Internet Banking. Journal of the Association for Information Systems, 1(1): 115-129.

Malhotra, P. and Singh, B. 2007. Determinants of internet banking adoption by banks in India. Journal of Internet Research, 17(3): 323-339.

Majid, K. 2012. Electronic banking challenges in India: an empirical investigation. Interdisciplinary Journal of Contemporary Research in Business, 4(2): 31-45.

Mohammad, A. 2010. E-Banking of Economical Prospects in Bangladesh. Journal of Internet Banking and Commerce, 15(2): 01-10.

Lal, R. and Saluja, R. 2012. E-banking: the Indian scenario. Asia Pacific Journal of Marketing \& Management Review, 4(1): $16-25$
Tan, M. and Teo, T.S.H. 2000. Factors influencing the adoption of internet banking. Journal of the Association of the Information System, 1(5): 1-42.

Taylor, S. and Todd, P. 1995. Understanding information technology usage: A test of competing models. Journal of Information Systems Research, 6(2): 144-176.

Taylor, M. and Murphy, A. 2004. SMEs and e-business. Journal of Small Business and Enterprise Development, 11(3): 280-289.

Siaw, I, and Yu, A. 2004. An analysis of the impact of the internet on competition in the banking industry, using porter's five forces model. International Journal of Management, 21(4): 514-522. 